ISSN 2524-2369 (Print)

ISSN 2524-2377 (Online)

\title{
ГІСТОРЫЯ
}

HISTORY

УДК 94:324(476)

https://doi.org/10.29235/2524-2369-2021-66-4-418-424

Поступила в редакцию 23.08.2021

Received 23.08.2021

\section{H. В. Барабаш}

Белорусский государственньй педагогический университет имени Максима Танка, Минск, Беларусь

\section{ПЕРВЫЕ ЖЕНЩИНЫ-ДЕПУТАТЫ ВЕРХОВНОГО СОВЕТА БССР ПЕРВОГО СОЗЫВА}

\begin{abstract}
Аннотация. На основе введения в научный оборот широкого круга раннее неизвестных источников впервые показано проведение выборов и избрание депутатов Верховного Совета БССР первого созыва 1938 г. Автором рассмотрены правовые основы упразднения Центрального Исполнительного Комитета БССР и создания в соответствии с Конституцией БССР 1937 г. высшего законодательного органа республики - Верховного Совета. Охарактеризована политика советской власти по вовлечению женщин в органы государственной власти и управления. Проведен количественный, социальный, образовательный анализ женщин-депутатов в высшем законодательном органе БССР первого созыва.

Ключевые слова: Конституция, БССР, Центральный Исполнительный Комитет, Верховный Совет БССР, Центральная Избирательная Комиссия, выборы, избирательный округ, депутат

Для цитирования: Барабаш, Н. В. Первые женщины-депутаты Верховного Совета БССР первого созыва / Н. В. Барабаш // Вес. Нац. акад. навук Беларусі. Сер. гуманіт. навук. - 2021. - Т. 66, № 4. - С. 418-424. https://doi. org/10.29235/2524-2369-2021-66-4-418-424
\end{abstract}

\section{Nataliya V. Barabash}

Maxim Tank Belarusian State Pedagogical University, Minsk, Belarus

\section{THE FIRST WOMEN-DEPUTIES IN THE SUPREME SOVIET OF THE BSSR OF THE FIRST CONVOCATION}

\begin{abstract}
The article, based on the introduction into scientific field a wide range of unknown sources, first shows the holding of elections and the election of deputies to the Supreme Soviet of the BSSR of the first convocation of 1938. The author considers the legal basis for theof the Central Executive Committee of the BSSR and the creation in accordance with the Constitution of the BSSR 1937 the highest legislative body of the republic - the Supreme Soviet. The author examines the policy of the Soviet government to include women to government and government bodies. A quantitative, social, educational analysis of women-deputies in the highest legislative body of the BSSR of the first convocation was carried out.

Keywords: The Constitution of the BSSR, the Central Executive Committee, the Supreme Soviet of the BSSR, the Central Election Commission, elections, constituency, deputy

For citation: Barabash N. V. The first women-deputies in the Supreme Soviet of the BSSR of the first convocation. Vestsi Natsyyanal'nai akademii navuk Belarusi. Seryia humanitarnykh navuk = Proceedings of the National Academy of Sciences of Belarus. Humanitarian Series, 2021, vol. 66, no. 4, pp. 418-424 (in Russian). https://doi.org/10.29235/2524-2369-202166-4-418-424
\end{abstract}

Введение. В СССР в середине 1930-х гг. было провозглашено построение основ социализма. Социалистические отношения стали господствующими в экономике, политике, социально-культурной сфере. Учитывая эти изменения и принятие новой Конституции СССР 1936 г., XII Чрезвычайный съезд Советов БССР принял 19 февраля 1937 г. Конституцию (Основной закон) Белорусской ССР.

(C) Барабаш Н. B., 2021 
Основная часть. Конституция БССР 1937 г. закрепила построение основ социализма в республике и полную ликвидацию эксплуататорских классов. Она полностью повторяла все основные положения Конституции СССР. Объявлялось, что вся власть в БССР принадлежит трудящимся города и деревни в лице Советов депутатов трудящихся [1, с. 190].

Конституция определила структуру и компетенцию государственных органов власти и управления. Впервые в Конституции намечался переход к разделению власти на законодательную, исполнительную и судебную. Согласно Конституции, законодательная власть принадлежала Верховному Совету, а в период между сессиями - Президиуму Верховного Совета БССР. Эти органы власти образовывались вместо ранее существующих - Всебелорусского съезда Советов, его Центрального Исполнительного Комитета и Президиума Исполнительного Комитета БССР [1, с. 191].

Президиум Верховного Совета БССР руководил организационно-массовой работой местных Советов, утверждал положения о выборах, решал вопросы административно-территориального деления в республике, ратифицировал международные договоры, осуществлял нормотворческую деятельность.

Исполнительная власть принадлежала Совету Народных Комиссаров, который являлся высшим исполнительным и распорядительным органом - правительством БССР. Он включал председателя правительства, его заместителей, председателя Государственной плановой комиссии, 14 народных комиссаров, 10 из которых относились к союзно-республиканским народным комиссариатам, а 4 - к республиканским. В члены правительства входили: уполномоченный Комитета по заготовкам СССР, начальник управления по делам искусств, уполномоченные общесоюзных народных комиссариатов [1, с. 192].

В значительной степени были перестроены местные органы государственной власти. Согласно Конституции, в округах, районах, городах, селах, местечках, деревнях, поселках органами государственной власти являлись Советы депутатов трудящихся. Окружные, районные, городские, районные в крупных городах, сельские, местечковые и поселковые Советы депутатов трудящихся избирались соответственно трудящимися округа, района, города, села, деревни, местечка, поселка сроком на два года. Они осуществляли руководство культурно-политическим и хозяйственным строительством на своей территории, устанавливали местный бюджет, руководили деятельностью подчиненных им органов управления, обеспечивали охрану государственного порядка, содействовали усилению обороноспособности страны, обеспечивали соблюдение законов и охрану прав граждан. В 1938 г. система местных органов была изменена: ликвидированы округа и созданы пять областей - Витебская, Гомельская, Минская, Могилевская и Полесская, в которых были избраны областные Советы депутатов трудящихся [1, с. 192].

Конституция БССР 1937 г. внесла принципиальные изменения в избирательную систему. Выборы во все Советы депутатов трудящихся - Верховный Совет БССР, областные, районные, городские, сельские и поселковые Советы проводились избирателями на основе всеобщего, равного и прямого избирательного права при тайном голосовании. По каждому округу выдвигался только один кандидат. Депутаты (1 от 20 тысяч избирателей) избирались на четыре года [1, с. 192].

Право выдвигать кандидатов в депутаты закреплялось только за партийными органами. Несмотря на то что такое право было закреплено за профсоюзами, кооперативами, молодежными организациями, культурно-просветительскими обществами, эти организации выдвигали своих кандидатов только по поручению партийных органов. Участвовать в выборах обязаны были все совершеннолетние граждане, отсутствие избирателя могло рассматриваться как саботаж выборов, что в тот период угрожало репрессиями. Поэтому в выборах, как правило, принимало участие 99,9\% всех избирателей, и все они голосовали только за одного кандидата, так как по каждому избирательному округу выдвигался только один кандидат [1, с. 193].

В Конституции объявлялась свобода слова, печати, собраний и митингов, уличных шествий и демонстраций, закреплялось равенство граждан, независимо от национальной принадлежности, расы, пола, вероисповедания, расширен круг прав и свобод граждан. Так, например, были предусмотрены нормы об обеспечении неприкосновенности личности, жилища, личной переписки и др. 
Конституцией БССР были утверждены герб, флаг республики (ст. 119 и 120), а также столица (ст. 121) [1, с. 162].

Таким образом, в Конституции БССР 1937 г. была закреплена победа социализма, господство социалистической системы хозяйствования и социалистической собственности; перерастание диктатуры пролетариата в общенародное государство; отменены ограничения избирательных прав; закреплено равенство граждан, расширен круг прав и свобод граждан.

26 июня 1938 г. впервые состоялись выборы в Верховный Совет БССР. В Беларуси было создано 3878 избирательных участков и 273 избирательных округа по выборам в Верховный Совет БССР. Из общего количества 3033643 избирателей в голосовании участвовало 3021787 избирателей, или 99,61\% населения БССР. Всего было избрано 273 депутата, из них белорусов - 167, русских 75 , евреев -20 , украинцев -6 , поляков -1 , грузин -1 , армян -1 , мордвинов -1 . Социальный состав избранных депутатов выглядел следующим образом: рабочих - 64, колхозников - 73, служащих -133 , военнослужащих - 3. Как следует, абсолютное большинство депутатов были белорусами, что являлось закономерным и отражало национальный состав населения Беларуси [2, л. 42$]$.

Сессия Верховного Совета БССР работала 25-28 июля 1938 г. [2, л. 44]. Первое вечернее заседание состоялось 25 июля 1938 г., его открыл депутат Верховного Совета БССР, профессор, доктор медицинских наук Мелких Сергей Михеевич. В своем выступлении он отметил социально-экономические, общественно-политические, культурные достижения Беларуси за годы советской власти, подчеркнул необходимость замены Центрального Исполнительного Комитета БССР Верховным Советом. С. М. Мелких в качестве председательствующего отметил, что в соответствии со ст. 26 Конституции БССР необходимо избрать Председателя Верховного Совета. Депутат В. П. Смоляр от имени группы депутатов Минской, Могилевской и Полесской областей внес предложение об избрании Председателем Верховного Совета БССР Грек Надежды Григорьевны, 3-го секретаря ЦК КП(б)Б депутата от Ветковского сельского округа Гомельской области. За избрание Н. Г. Грек единодушно проголосовали все депутаты [3, с. 19].

Затем по процедуре были избраны два заместителя Председателя. Ими стали Майоров Дмитрий Никифорович - начальник паровозной службы Витебского отделения Западной железной дороги, Борушков Григорий Минович - заведующий овцеводческой фермой колхоза «Гомельский пролетарий» Гомельской области [2, л. 4].

Для повседневной работы и руководства деятельностью Верховного Совета БССР был избран Президиум Верховного Совета БССР, который возглавил Наталевич Никифор Яковлевич, два его заместителя - Мельников Сергей Петрович и Мальцев Сергей Иванович, а также секретарь Президиума - Папков Лазарь Евдокимович [2, л. 49].

После избрания заместителей был принят регламент работы Верховного Совета. Заседания сессий происходили с 11 до 15 часов и с 18 до 20 часов. На этом же заседании была утверждена повестка дня первой сессии, на которую были вынесены следующие вопросы: 1) выборы мандатной комиссии; 2) избрание постоянных комиссий; 3) внесение изменений и дополнений в некоторые статьи Конституции БССР; 4) избрание Президиума Верховного Совета БССР; 5) образование правительства БССР - Совета Народных Комиссаров; 6) о возмещении депутатам Верховного Совета расходов, связанных с выполнением депутатских обязанностей [2, л. 5].

На втором заседании председатель Мандатной комиссии В. Г. Шибалко сообщил депутатам, что в результате проверки всех материалов Мандатная комиссия установила, что выборы депутатов в Верховный Совет БССР по всем 273 избирательным округам состоялись в соответствии с Конституцией БССР и «Положением о выборах в Верховный Совет Белорусской ССР». Он отметил, что в составе депутатов Верховного Совета БССР рабочих - 103 человека, крестьян - 103, служащих и представителей интеллигенции - 67 человек [2, л. 12].

Среди депутатов 40 человек непосредственно работали в сельском хозяйстве, из них председателями колхозов - 20 человек, заместителями председателей колхозов, бригадирами, доярками в колхозах, заведующими МТКФ, телятницами и свинарками, звеньевыми колхозов, рядовыми колхозниками и колхозницами - 20 человек [2, л. 12]. В составе депутатов имеется 19 работников MTC, из них 8 трактористов, 2 комбайнера, 7 бригадиров тракторных бригад, 2 директора МТС. В составе депутатов были 5 работников предприятий, директоров фабрик и заводов и их замести- 
телей, 1 начальник цеха, 1 мастер, 1 бригадир, 13 рабочих предприятий и железнодорожного транспорта [2, л. 12].

Депутатами были избраны 68 работников советских органов, из них 5 председателей облисполкомов, 5 заместителей председателей облисполкомов, 3 секретаря облисполкомов, 17 председателей райисполкомов, 3 председателя городских советов, 6 председателей сельских советов, 11 наркомов и их заместителей, 2 работника суда и прокуратуры и других [2, л. 12 об.].

В составе депутатов было всего лишь 49 человек с высшим образованием, 72 - со среднеспециальным, 4 - с незаконченным высшим образованием и 3 с незаконченным средним образованием, 145 - с низшим образованием. Половина депутатов - 128 человек - имели среднее и высшее образование [2, л. 13].

По возрасту депутаты Верховного Совета БССР распределялись следующим образом: до 20 лет - 4 человека, от 21 до 25 лет - 38, от 26 до 30 лет - 39, от 31 до 35 лет - 99, от 36 до 40 лет - 41, от 41 до 50 лет - 46, свыше 50 лет - 6 человек. Таким образом, большая часть депутатов имели возраст от 31 до 35 лет. Молодой состав депутатского корпуса характеризуется тем, что в его составе имелось 4 депутата до 20-летнего возраста, 8 депутатов до 25-летнего возраста, 39 депутатов до 30-летнего возраста [2, л. 13].

Первая сессия Верховного Совета БССР утвердила высший исполнительный орган нашей республики - Совет Народных Комиссаров, его председателя - Киселева Кузьму Венедиктовича и его заместителей - Захарова Ивана Антоновича и Кулагина Михаила Васильевича [2, л. 42 об.]. Также были утверждены все народные комиссары - 14 народных коммисаров, Председатель государственной плановой комиссии, начальник управления по делам искусств и начальник дорожного управления. С утверждением правительства БССР первая сессия Верховного Совета БССР 1938 г. закончила свою работу.

В Верховный Совет БССР первого созыва 1938 г. было избрано 68 женщин, которые представляли всю социальную структуру белорусского общества и отражали все ее слои - рабочие, интеллигенция, трудящиеся, представители партийно-советских, комсомольских и профсоюзных органов [4, л. 23].

Огромную роль в проведении выборов и избрании депутатов в Верховный Совет БССР 1938 г. первого созыва сыграла председатель Центральной Избирательной Комиссии БССР Абушенко Клавдия Амосовна, избранная депутатом Верховного Совета БССР. Ее политическая карьера началась в 1923 г., когда первая в Россонском районе комсомольская организация деревни Горбачево приняла в свои ряды 16-тилетнюю Клаву Абушенко из деревни Городно. Молодая комсомолка оказалась трудоспособной и энергичной. По ее инициативе и при непосредственном участии активизировалась борьба с неграмотностью, читались лекции, был создан драматический кружок в ее родной деревне. Молодую и энергичную комсомолку заметили и избрали делегатом Полоцкой окружной конференции комсомола. После конференции переход на комсомольскую работу: секретарь ячейки комсомола деревни Горбачево, пионервожатая, женорганизатор, член Россонского райкома комсомола - вот далеко не полный перечень ее должностей, с которыми она успешно справлялась. В 1928 г. Клавдия Абушенко - работница Витебской чулочно-трикотажной фабрики имени Клары Цеткин. В 1937 г. она окончила Высшую коммунистическую сельскохозяйственную школу и была направлена на должность председателя союза мясомолочных совхозов. Однако на этой должности она не успела долго проработать. С началом избирательной кампании Клавдию Абушенко выдвинули председателем Центральной Избирательной Комиссии по выборам в Верховный Совет БССР. Помимо этого, 4 июня 1938 г. на первом заседании нового состава пленума Минского ОК КП(б)Б ее избирают третьим секретарем обкома партии. Несмотря на совмещение ответственных должностей, всю избирательную кампанию она проводит безукоризненно и избирается депутатом Верховного Совета БССР от Заславльского сельского избирательного округа [5, с. 3].

Первым быть всегда трудно, особенно если ты молодая женщина и занимаешь в соответствии с Конституцией БССР высший государственный пост в республике. Надежда Григорьевна Грекова в 28 лет стала не только депутатом Верховного Совета БССР, но и была избрана его 
Председателем. Н. Грекова являлась единственной женщиной в истории Советского Союза, избранной на такой высокий пост на выборах 1938 г. [3, с. 18].

Ее партийно-государственная карьера характерна для того времени. Двадцатилетней Надежда Грек вступает во взрослою жизнь, поступив в профшколу швейников. В 1927 г. Надежда, получив диплом об окончании школы, поступает на работу на фабрику «Миншвея» в Минске. С первых дней работы на фабрике она «включается» в активную общественно-политическую жизнь, участвуя в комсомольской и профсоюзной работе. Ее активность, умение работать с людьми, коммуникабельность и деловитость способствовали тому, что она избирается членом Президиума Центрального правления союза швейников. С 1933 по 1937 г. Н. Грекова работает заместителем председателя и председателем Центрального правления союза швейников. Организаторские способности Н. Грековой особенно проявились, когда она являлась председателем Центральной Избирательной Комиссии по выборам в Совет Национальностей СССР в 1938 г. На этой должности она зарекомендовала себя безупречно. В 1938 г. ее приглашают на работу в ЦК КП(б)Б в качестве заведующего промышленным отделом ЦК [6, с. 4], и в этом же году ее избирают в Верховный Совет БССР, а на первой сессии депутаты единогласно избирают ее Председателем Верховного Совета БССР.

Депутатом Верховоного Совета БССР была избрана Уралова Евдокия Ильинична - нарком образования БССР. Свою политическую карьеру Евдокия Уралова начала с работы учителя начальных классов. В 1921-1929 гг. Евдокия Уралова работала учительницей начальных классов в сельских школах Климовичского уезда и Рославльского уезда, женорганизатором Петровичского волостного комитета Рославльского уезда, инструктором Рославльского уездного комитета партии, народным судьёй города Рославля. В 1926 г. она вступила в партию большевиков. В 1931-1937 гг. Евдокия Ильинична работает прокурором в Дорогобуже, Вязьме и Полоцке. В 1937-1938 гг. Е. Уралова избирается вторым секретарём Полоцкого окружного комитета КП(б)Б, а в 1938 г. - первым секретарём Полоцкого райкома партии. В июне 1938 г. она избирается в Верховный Совет БССР первого созыва. В августе 1938 г. она назначается наркомом просвещения БССР. Именно на этой должности особенно раскрылись её организаторские способности и лучшие деловые качества.

В Верховный Совет были избраны опытные производственники. Свою производственную деятельность Евгения Соломоновна Ханина начала в 1921 г., когда молоденькой девушкой пришла на работу на Витебскую чулочно-трикотажную фабрику имени Клары Цеткин и начала работать мотальщицей, а затем штопальщицей. В 1922 г. она кардинально меняет свою судьбу и связывает ее с комсомолом. Девушка избирается секретарем фабричной комсомольской ячейки, на следующий год - секретарем райкома комсомола, далее - членом бюро Витебского окружкома комсомола и членом ЦК комсомола Беларуси. В 1931 г. ее назначают заместителем директора чулочно-трикотажной фабрики имени Клары Цеткин и в этом же году - директором и, как оказалось, чрезвычайно успешным. Сегодня бы ее охарактеризовали как успешного менеджера. В 1931 г. коллектив фабрики заносится на республиканскую Красную доску передовиков. План первой пятилетки коллектив фабрики выполнил за два года, за что Е. Ханина была награждена грамотой ЦИК БССР. В этой должности она проработала 5 лет. Молодого и успешного руководителя (в 1936 г. ей исполнилось 33 года) назначают директором Витебской чулочно-трикотажной фабрики имени КИМ - первенца первой пятилетки. Итог руководства Евгении Ханиной восьмитысячным коллективом впечатляющий: два переходящих знамени Наркомлегпрома СССР и Витебского горкома КП(б)Б. В 1938 г. Евгения Ханина избирается депутатом Верховного Совета БССР по Витебскому избирательному округу [7, с. 3].

Депутатами Верховного Совета были избраны многие представители аграрного сектора республики. От Гомельской области Тереховского района Ленинского избирательного округа депутатом была избрана председатель колхоза «Вольная праца» Анна Тихоновна Короленко. Несмотря на молодость, она уже была известна в республике как знатная льноводка. За значительные успехи в выращивании льна правительство СССР наградило ее Орденом «Знак Почета». Районное руководство выдвинуло ее на работу председателем колхоза [8 с. 3]. 
В Могилевском районе Евфимию Михайловну Алексейчикову называли «Белорусская Паша Ангелина». На момент избрания депутатом высшего законодательного органа Беларуси ей исполнился всего 21 год. В 1935 г. 19-летняя Евфимия работала заведующей детскими яслями в колхозе «Победа» Щежарского сельсовета Могилевского района и, казалось бы, что вся ее жизнь и в дальнейшем будет связана с воспитанием детей. Однако осенью 1935 г. кардинально изменилась вся ее судьба. В один из осенних дней она пришла в правление колхоза и заявила, что хотела бы работать в колхозе трактористкой. Члены правления колхоза решили направить девушку на курсы трактористов в Могилевскую машинно-тракторную станцию (МТC). К весне 1936 г. ее мечта сбылась. Энергичная трактористка зимой 1936 г. отправляется на курсы льнотеребильщиков, в 1937 г. дополнительно заканчивает курсы шоферов и во всех трех специальностях она не только успешно «конкурирует» с мужчинами, но и опережает их. По итогам социалистического соревнования 1937 г. среди трактористов Луполовской МТС она занимает первое место. Целеустремленность, нацеленность на лучшие показатели, трудолюбие и ответственность были замечены и по достоинству оценены руководством района. Она была выдвинута и избрана депутатом Верховного Совета БССР [8, с. 3].

Анна Васильевна Муравьева к моменту избрания депутатом Верховного Совета БССР, в отличие от Евфимии Алексейчиковой, уже имела большой стаж работы. Она не только сама работала трактористкой, но и являлась бригадиром женской тракторной бригады Высочанской МТС Лиозненского района Витебской области. Девушка была избрана депутатом Верховного Совета БССР от Высочанского избирательного округа $[9$, с. 3].

Высокую номенклатурную должность занимала Елена Киреевна Жур - председатель Пуховичского райисполкома, которая была избрана депутатом от Гореличского избирательного округа Пуховичского района [9, с. 3]. Опытным работником пришла в Верховный Совет БССР Вера Филипповна Харланова - секретарь Климовичского райкома партии, которая была избрана по Климовичскому сельскому избирательному округу [10, с. 3].

В 1920 - 1930-е гг. люди быстро взрослели и становились талантливыми организаторами производства и хорошими управленцами. Не исключением из этого правила стала самый молодой депутат Верховного Совета БССР Анна Ивановна Пальцева, которой на момент избрания депутатом исполнилось только 19 лет. Однако к этому возрасту она уже была известной белорусской стахановкой. В свои 19 лет девушка заведовала крупнейшей молочно-товарной фермой колхоза «Чырвоны дубровец» Глусского района. В 1936 г. ее избирают делегатом Всебелорусского съезда передовиков животноводства, где она делится опытом своей работы. А опыт уже был накоплен значительный. Ферма, которую она возглавляла, насчитывала 315 голов крупного рогатого скота, которые давали 20000 литров молока в год [11, с. 3]. Не каждый район в республике мог похвастаться такими результатами и, безусловно, огромная доля в этом успехе принадлежала Анне Ивановне Пальцевой.

В истории страны 1930-е гг. занимают особое место. Это годы индустриализации, время модернизации старых и создания новых предприятий. Новое время потребовало подготовки новых инженерных кадров. Одним из природных богатств Беларуси является лес. Для подготовки кадров для лесотехнической промышленности в 1930 г. был создан лесотехнический институт в Гомеле, который в 1935 г. окончила Нина Григорьевна Стасенко. По распределению она была направлена на работу в г. Горький на машиностроительный завод, где трудилась инженером по деревообработке. Через год она возвращается на родину и работает на Гомсельмаше. Опыт работы на крупных предприятиях, целеустремленность, организаторские способности молодого инженера были замечены и в 1937 г. ее направляют на работу в Рогачев на лесозавод им. Халтурина, где назначают начальником сушильно-тарного цеха, а по совместительству ответственной за весь процесс деревообработки на заводе. В 1938 г. Нина Григорьевна Стасенко избирается депутатом высшего законодательного органа БССР - Верховного Совета [12, с. 3].

Среди 14 народных комиссаров было две женщины-депутата: Уралова Евдокия Ильинична нарком просвещения и Гутенкова Евдокия Трофимовна - нарком социального обеспечения [2, л. 49]. 
Заключение. Избрание в высший законодательный орган 68 женщин было закономерным и обоснованным решением высшего партийно-советского руководства Беларуси. Подбор и выдвижение женщин на руководящую партийно-советскую, хозяйственную, комсомольскую и профсоюзную работу отражали линию партии на вовлечение женщин в активное социалистическое строительство. Женщины наравне с мужчинами ответственно и добросовестно работали на всех постах и должностях - начиная от районного и заканчивая республиканским уровнем.

\section{Список использованных источников}

1. Круталевіч, В. А. Гісторыя дзяржавы і права Беларусі (1919-1945 гг.) : вучэб. дапам. / В. А. Круталевіч, І. А. Юхо. - 2-е выд. - Мінск : Беларус. навука, 2000. - 238 с.

2. Национальный архив Республики Беларусь (НАРБ). - Ф. 968. Оп. 1. Д. 4. Л. 4, 5, 12, 12об., 13, 42, 44, 49, 50. Подлинник.

3. Голубева, Н. А. Надежда Грекова. Михаил Малинин: время помнить / Н. А. Голубева. - Минск : Белорус. Эн-цикл., 2020. -367 с.

4. НАРБ. - Ф. 4п. Оп. 1. Д. 17010. Л. 23. Подлинник.

5. Клавдия Амосовна Абушенко // Совет. Белоруссия. - 1938. - 19 июня. - С. 3.

6. Надежда Грек // Звязда. - 1938. - 19 июня. - С. 3.

7. Евгения Соломоновна Ханина // Совет. Белоруссия. - 1938. -22 июня. - С. 3.

8. Верная дочь Родины // Совет. Белоруссия. $-1938 .-3$ июня. - С. 3.

9. Елена Киреевна Жур // Совет. Белоруссия. - 1938. - 5 июня. - С. 3.

10. Вера Филипповна Харланова // Совет. Белоруссия. - 1938. - 16 июня. - С. 3.

11. Анна Ивановна Пальцева // Совет. Белоруссия. - 1938. - 8 июня. - С. 3.

12. Нина Григорьевна Стасенко // Совет. Белоруссия. - 1938. - 11 июня. - С. 3.

\section{References}

1. Krutalevich V. A., Yukho I. A. History of the State and law of Belarus (1919-1945). $2^{\text {nd }}$ ed. Minsk, Belaruskaya navuka Publ., 2000. 238 p. (in Belarusian).

2. The National Archive of the Republic of Belarus (NARB). F. 968. Op. 1. D. 4. L. 4, 5, 12, 12ob, 13, 42, 44, 49, 50. The original. (in Russian).

3. Golubeva N. A. Nadezhda Grekova. Mihail Malinin: time to remember. Minsk, Belorusskaya Entsiklopediya Publ., 2020. 367 p. (in Russian).

4. The National Archive of the Republic of Belarus (NARB). F. 4p. Op. 1. D. 17010. L. 23. The original. (in Russian).

5. Klavdia Amosovna Abushenko. Sovetskaya Belorussiya [Soviet Belarus], 1938, June 19, p. 3 (in Russian).

6. Nadezhda Grek. Zvyazda [Star], 1938, June 19, p. 3 (in Russian).

7. Evgenia Solomonovna Khanina. Sovetskaya Belorussiya [Soviet Belarus], 1938, June 22, p. 3 (in Russian).

8. The faithful daughter of the Motherland. Sovetskaya Belorussiya [Soviet Belarus], 1938, June 3, p. 3 (in Russian).

9. Elena Kireevna Zhur. Sovetskaya Belorussiya [Soviet Belarus], 1938, June 5, p. 3 (in Russian).

10. Vera Filippovna Kharlanova. Sovetskaya Belorussiya [Soviet Belarus], 1938, June 16, p. 3 (in Russian).

11. Anna Ivanovna Paltseva. Sovetskaya Belorussiya [Soviet Belarus], 1938, June 8, p. 3 (in Russian).

12. Nina Grigoryevna Stasenko. Sovetskaya Belorussiya [Soviet Belarus], 1938, June 11, p. 3 (in Russian).

\section{Информация об авторе}

Барабаш Наталья Викторовна - кандидат исторических наук, доцент. Белорусский государственный педагогический университет имени Максима Танка (ул. Советская, 18, 220030, Минск, Республика Беларусь). Е-mail: barabash-n@bh.ru

\section{Information about the author}

Nataliya V. Barabash - Ph. D. (Hist.), Associate Professor. Maxim Tank Belarusian State Pedagogical University (18 Sovetskaya Str., Minsk 220030, Belarus). E-mail: barabashn@bh.ru 